Nig. J. Biotech. Vol. 38 (1) : 146-153 (June 2021)

ISSN: 01891731

Available online at

http://www.ajol.info/index.php/njb/index

and www.biotechsocietynigeria.org

DOI: https://dx.doi.org/10.4314/njb.v38i1.17

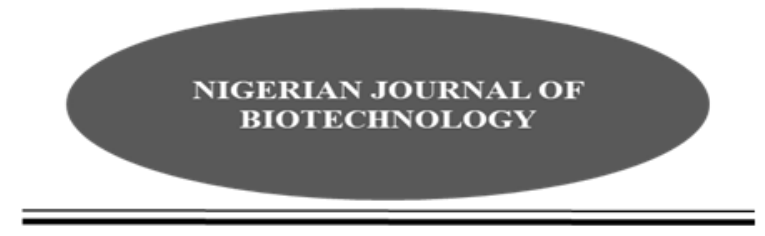

\title{
Effect of Aqueous Leaf Extract of Jatropha tanjorensis on parasitaemia and haematological parameters in mice infected with Plasmodium ber ghei
}

\author{
${ }^{1}$ Ebenyi, L. N., ${ }^{1,2}$ Yongabi, K. A., ${ }^{1}$ Ali, F. U., ${ }^{1}$ Ominyi, M. C., ${ }^{1}$ Anyanwu, C. B., \\ ${ }^{1}$ Benjamin, E. and ${ }^{3}$ Ogbanshi, M. E. \\ ${ }^{1}$ Department of Biotechnology, Ebonyi State University, P. M. B. 043, Abakaliki. \\ ${ }^{2}$ Department of Public Health, Faculty of Health Sciences, Imo State University, Owerri, Nigeria \\ ${ }^{3}$ Department of Biochemistry, Ebonyi State University, Abakaliki
}

\begin{abstract}
Medicinal plants are proven sources of many useful drugs in our modern world. Jatropha tanjorensis, known as hospital too far, is consumed highly in Africa as herbal medicine. This research work was done to evaluate the effect of aqueous leaf extract of Jatropha tanjorensis on parasitaemia and haematological parameters in mice infected with Plasmodium ber ghei. The leaves of $J$. tanjorensis were extracted with distilled water and qualitative phytochemical analysis carried out. Acute toxicity studies were carried out using the Organization for Economic Cooperation and Development (OECD) guideline. The curative activity of the extract was examined using Rane's test. A total of forty (40) mice were used for the study and they were infected with Plasmodium berghei. The infected mice were subdivided into five groups of six mice each and treated with different doses of standard drug (artemether/lumefantrine $25 \mathrm{mg} / \mathrm{kg}$ ) and extract $(200,400$ and $800 \mathrm{mg} / \mathrm{kg}$ body weight) for 4 days. After treatment, blood was collected and used for percentage parasitaemia, packed cell volume and hemoglobin concentration. The result of phytochemical analysis revealed the presence of alkaloids, tannins, saponins, flavonoids, terpe noids, cardiac glycosides and anthra quinones. The result of the acute toxicity showed the signs of neither neurological, behavioral nor mortality at concentrations of 2,000 and $5,000 \mathrm{mg} / \mathrm{kg}$ oral doses within the first 24 hours and during the 14 days study period. A dose- dependent increase was observed in Total haemoglobin (Hb) and Packed cell volume (PCV) levels which was collaborated with increase in weight as compared with negative control. The leaf extract of $J$. tanjorensis also revealed a significant $(\mathrm{p}<0.05)$ suppression activity and mean survival time at the doses of $400 \mathrm{mg} / \mathrm{kg}, 200 \mathrm{mg} / \mathrm{kg}$ and $100 \mathrm{mg} / \mathrm{kg}$ when compared with the negative control. The extract of Jatropha tanjorensis showed reasonable levels of anti-anaemia and antimalarial activities with no signs of acute toxicity. Therefore this study may support its use as an anti-prophylactic and blood tonic nutraceutical .
\end{abstract}

Keywords: Malaria, Anaemia, Medicinal plant, Jatropha tanjorensis, Antimalaria drug. Corresponding email: Lilian.ebenyi@ebsu.edu.ng

Introduction

Malaria is an infectious disease caused by a protozoan parasite belonging to the genus Plasmodium (WHO, 2014). This mosquito - borne illness affects humans and other animals, with a high annual mortality rate in the tropical zones (Mboowa, 2014). Pregnant women and children below the age of 5 years are the most exposed to 
the disease (Jigam et. al., 2011). Transmission is by an infected anopheles mosquito bite which introduces the parasites into a person's blood. The parasites enter the host liver cells where they mature and multiply. The symptoms of malaria which manifest 10 - 15 days after being bitten include tiredness, headache, fever and vomiting. In complicated cases, it leads to anaemia, yellowish skin, seizures and finally death (Mojarrab et. al., 2014). The effects of malaria are quite devastating, as it can cause several life-threatening complications and is one of the leading causes of death worldwide (Nayyar et. al., 2012). Anaemia, a common complication of malaria, is a common blood disorder affecting people of all ages, although the elderly, young women of child-bearing age and the infants are at greater risk (Ehimwenma and Osagie, 2007). This is characterized by a reduction in Packed Cell Volume (PCV), Haemoglobin Concentration $(\mathrm{Hb})$ and Red Blood Cells Count (RBC) (Mengiste et. al., 2012). The anaemia prevalence remains high in Africa, with an overall incidence of $64.6 \%$ in children, $55.8 \%$ among pregnant women and $44.4 \%$ among young girls. The incidence of anaemia is more prevalent in the third world countries due to the presence of many aggravating factors such as malnutrition and high prevalence of blood parasites like, plasmodium, trypanosomes and helminthes infestation (Center for Disease Control and Prevention, 2015). Internationally and in Africa, there is a reduction in malaria mortality rates since the year 2000 by 47 and 54 $\%$ respectively (WHO, 2014).

In countries where malaria is endemic, orthodox and traditional medicines are commonly used in treatment of malaria. There are over 1200 species and over 160 families of plants recognized in herbal medicine for the treatment of malaria (Hagazy et al., 2020). Jatropha tanjorensis commonly called "hospital too far" which belongs to the family Euphorbiaceae, originated from Central America and has spread in many tropical and sub tropical countries, including Africa, India and North America (Prabakaran and Sujatha, 1999). The primary use of $J$. tanjorensis is for fencing while it is secondarily eaten as vegetables and herbal remedies (Oboh and Masodje, 2009). A lot of attention is placed on J. tanjorensis and people who consume it are said to hardly fall ill due to its assumed health benefits, availability and affordability (Falodun et al., 2013). A review on the pharmacological studies showed a wide range of biological activities such as the leaves are used in many parts of Nigeria for the treatment of many illnesses and as a blood tonic (Iwelewa et. al., 2005). A research by Omobuwajo, 2011 on the toxicological and histological effect of the leaf extract on rats revealed no significant harmful effect in the tissues other than for a minor effect on the lungs and liver. The ethanol/ water (1:1) extract was reported to have a significant glucose lowering activity in glucose loaded rats (Olayiwola et. al., 2004). J. tanjorensis leaves are employed traditionally in the treatment of diseases such as anaemia, diabetes and cardiovascular illnesses. The leaf extract also has hypoglycemic activities and it is consumed as medicine for diabetes patients (Olayiwola et. al., 2004). The antioxidant potential of the leaf extract has been investigated and was discovered to have antioxidant potential against reactive oxygen species (Ehimwenma and Osagie, 2007). In view of the numerous uses of J. tanjorensis in herbal medicine, this work was done to determine the anti plasmodial and antianaemia effect of aqueous leaf extract of Jatropha tanjorensis in mice infected with Plasmodium berghei.

\section{Materials and Methods}

Collection of plant material

The plant, Jatropha tanjorensis, was obtained within Abakaliki metropolis, Ebonyi State. The plant was dried under shade and ground into powdered form.

\section{Experimental Animals used}

Albino mice were obtained from the animal house in the Faculty of Veterinary Medicine, University of Nigeria Nsukka. The mice were acclimatized for 1 week in the animal house of the Department of Biotechnology, Ebonyi State University, Abakaliki and fed with food and water ad libitum.

\section{Preparation of Crude Extract}

Two hundred (200) grams of the powdered plant was weighed and poured into a clean vessel. Two thousand (2000) milliliters of distilled water was boiled to $100{ }^{\circ} \mathrm{C}$ and poured into the vessel containing the weighed plant. The air tight mixture was kept for 48 hours and shaken intermittently. After 48 hours, the mixture was sieved, evaporated to dryness and transferred to a new sterile container before it was stored.

Phytochemical Screening

Screening for the secondary metabolites present in aqueous leaf extract of Jatropha tanjorensis 
was done using the method described by Fentahun and Makonnen, 2017.

Acute Oral Toxicity

Evaluation of the acute oral toxicity of aqueous leaf extract of $J$. tanjorensis was done using the procedure by the Organization for Economic Cooperation and Development (OECD). The animals were starved for 3 hours then divided into four groups of two, two, three and four mice per group. Groups 1 and 2 were treated with 2000 $\mathrm{mg} / \mathrm{kg}$ and $5000 \mathrm{mg} / \mathrm{kg}$ of extract, observed over a period of 24 hours for signs of toxicity. In the absence of any recorded deaths, groups 3 and 4 were treated with $2000 \mathrm{mg} / \mathrm{kg}$ and $5000 \mathrm{mg} / \mathrm{kg}$ of extract then observed from 24 hours to 14 days. Behavioural abnormalities for signs of toxicity were recorded.

Parasite Infection of Experimental Animals

A parasitized mouse was obtained from the Veterinary medicine animal house, University of Nigeria, Nsukka. The infected mouse with a parasitemia level of $20-30 \%$ was sacrificed under anesthesia and blood collected through cardiac puncture. The blood collected into a heparinized tube was diluted with normal saline such that $1 \mathrm{ml}$ of blood contained $5 \times 10^{7}$ parasites. Thirty (30) experimental mice were then treated with $1 \times 10^{7}$ of parasitized blood via intraperitoneal route.

\section{Grouping and Dosing of Animals}

The forty (40) infected and non-infected mice used in the course of this experiment were randomly divided into six groups after seventy two (72) hours to determine the curative effect of aqueous leaf extract of Jatropha tanjorensis. Group 1 were normal, group 2 were infected without treatment, group 3 were infected and treated with standard drug (artemether + lumefantrine combined therapy), group 4 - 6 were infected and treated with extracts (100, 200 and $400 \mathrm{mg} / \mathrm{kg}$ body weight). After four days of daily administration of the extracts, the mice were anaesthet ized with chloroform and blood samples were collected from the whole mice sample using a capillary tube through the eyes of each mice and stored in EDTA bottles for analysis of the Red Blood Cell (RBC), Packed Cell Volume $(\mathrm{PCV}), \mathrm{H}$ aemoglobin ( $\mathrm{Hb})$ count and percentage parasitemia count.

Determination of Red Blood Cell (RBC)

Total red blood cells were determined by the method of Baker et. al. (1998). A solution of tris sodium citrate (31.1 gram per liter) was prepared to fix the red blood cells and destroy the white blood cells. Five hundred (500) $\mathrm{mL}$ of formalin was added to the dissolved sodium citrate for preservation of the solution. A 1 in 20 dilution was made for RBC. The Neubauer counting chamber was charged and filled with the solution and the red blood cells were counted under a light microscope.

\section{Determination of packed cell volume (PCV)}

The packed cell volume was determined by the method of Mengiste et. al. (2012). Blood was collected from the EDTA bottle into heparinized microh ematocrit capillary tubes. Up to $3 / 4^{\text {th }}$ volume of the capillary tubes were filled with the blood and sealed at the ends. The tubes were sealed with plasticine and placed on a microhematocrit centrifuge with the sealed ends outwards and centrifuged for 10 minutes at $11,000 \mathrm{rpm}$. After centrifugation, the erythrocytes volume were measured using a micro Hematocrit Reader and PCV was determined by

$\mathrm{PCV}=$ Volume of erythrocytes in a given volume of blood

Total blood volume

Determination of Haemoglobin $(\mathrm{Hb})$

Total haemoglobin was determined by the method of Von Scheuck, (1986). The haemoglobin was calculated as packed cell volume minus one (1) divided by three (3).

\section{Determination of percentage parasitemia}

The percentage parasitaemia (Mp) was determined by the method of Fenta and Kahaliw, 2019. The tail blood from each mice were fixed in methanol and stained with Giemsa to prepare a thin blood film that revealed parasitized erythrocytes. Parasitemia was examined using a light microscope while percentage parasitemia was calculated as the number of infected RBCs divided by total number of RBCs counted multiplied by 100 .

\section{Determination of percentage suppression}

The percentage suppression was determined by the method of Collison and Vignali (2011). The percentage suppression of parasitemia was calculated as

$\%$ suppression $=100-$ Mean parasitemia (crude extract) treated $\times 100$

Mean parasitemia 


\section{Determination of mean survival time (MST)}

The mean survival time was determined by the method of Fenta and Kahaliw, 2019. Daily mortality rate was monitored and recorded from the time of inoculation of $P$. berghei up to death for all the mice in all groups throughout the research period.

MST $=\underline{\text { Sum of survival days of all mice in a group }}$ Total number of mice in a group

\section{Data analysis}

Mean \pm standard error of mean $(\mathrm{M} \pm \mathrm{SEM})$ were used to express the results of the study. SPSS Window Version 16.0 was used for Data analysis. Statistical significance was determined by Oneway analysis of variance (ANOVA) followed by
Post-hoc Tukey's test for comparison of parasitemia, RBC, $\mathrm{Hb}, \mathrm{PCV}$ and body weight, among groups. A 95\% confidence interval and $P$ value less than 0.05 for parasitemia was considered to be statistically significant.

\section{Results}

Qualitative Phytochemical Analysis of Jatropha tanjorensis

Aqueous extraction of the powdered plant yielded $115 \mathrm{~g}$ of dark green color extract. The phytochemical result as shown in Table 1 revealed the presence of alkaloids, tannins, saponins, flavonoids, terpe noids, cardiac glycosides and anthra quinones while steroids and ph lobatannins were absent.

Table 1: Phytochemicals present in aqueous leaf extract of J. tanjorensis

\begin{tabular}{|c|c|}
\hline Phytochemicals & Extract \\
\hline Alkaloids & + \\
\hline Tannin & + \\
\hline Saponin & + \\
\hline Flavonoids & + \\
\hline Steroids & - \\
\hline Terpe noids & + \\
\hline $\mathrm{Ph}$ lobatannins & - \\
\hline Cardiac glycosides & + \\
\hline Anthra quinones & + \\
\hline Where $(+)$ : present and $(-)$ : absent & \\
\hline Acute Oral Toxicity Test & Effect of J. tanjorensis aqueous leaf Extract on \\
\hline Aqueous leaf extract of Jatropha tanjorensis & Body weight of mice \\
\hline $\begin{array}{l}\text { showed the signs of neither neurological, } \\
\text { behavioral nor mortality at concentrations of } \\
2,000 \text { and } 5,000 \mathrm{mg} / \mathrm{kg} \text { oral doses within the } \\
\text { first } 24 \text { hours and during } 14 \text { days study period. }\end{array}$ & $\begin{array}{l}\text { The results of the measurement of the infected } \\
\text { mice before and after treatment showed that the } \\
\text { treated groups showed a significant increase in } \\
\text { weight as compared with negative control which } \\
\text { was treated with only water as seen in Table } 2 \text {. }\end{array}$ \\
\hline
\end{tabular}

Table 2: Body weight ( $\mathrm{D} 0$ and $\mathrm{D} 4$ ) of Plasmodium infected mice treated with J. tanjorensis

\begin{tabular}{|c|c|c|c|c|}
\hline Test sample & Dose $(\mathrm{mg} / \mathrm{kg})$ & $\begin{array}{l}\text { Body } \\
\text { Before }\end{array}$ & After & $\begin{array}{c}\text { \% change in } \\
\text { BWT }\end{array}$ \\
\hline NC & 10 & $25.84 \pm 0.25$ & $22.00 \pm 0.40$ & -14.86 \\
\hline SD & 25 & $29.22 \pm 0.26$ & $35.02 \pm 0.46$ & 19.85 \\
\hline Extract & 100 & $27.67 \pm 0.21$ & $32.75 \pm 0.32$ & 18.36 \\
\hline Extract & 200 & $25.00 \pm 0.32$ & $34.50 \pm 0.39$ & 38.00 \\
\hline Extract & 400 & $30.00 \pm 0.28$ & $33.33 \pm 0.21$ & 18.36 \\
\hline
\end{tabular}

Values were presented as mean $\pm \mathrm{SEM} ; \mathrm{n}=5 ; \mathrm{NC}=$ negative control, $\mathrm{SD}=$ standard drug, $\mathrm{BWT}=$ body weight; ${ }^{a}$ Differs significantly with negative control.

Effect of J. tanjorensis aqueous leaf Extract on Total Haemoglobin $(\mathrm{Hb})$

The effect of aqueous leaf extract of $J$. tanjorensis on Total haemoglobin $(\mathrm{Hb})$ is presented in Table 3. The results of the study showed that the administration of the extract increased the haemoglobin levels as compared with the negative control. 
Table 3: Effect of J. tanjorensis aqueous leaf Extract on Total Hemoglobin $(\mathrm{Hb})$ level in infected mice

\begin{tabular}{lccc}
\hline Test sample & Dose $(\mathrm{mg} / \mathrm{kg})$ & Pretreatment & Post treatment \\
NC & 10 & $6.56 \pm 0.31$ & $6.00 \pm 0.41$ \\
SD & 25 & $7.00 \pm 0.33$ & $12.47 \pm 0.22 * a$ \\
Extract & 100 & $6.98 \pm 0.29$ & $10.00 \pm 0.30 * a$ \\
Extract & 200 & $5.95 \pm 0.11$ & $23.25 \pm 0.20^{* a, b}$ \\
Extract & 400 & $6.80 \pm 0.21$ & $15.00 \pm 0.33^{* a}$
\end{tabular}

Notes: Values are presented as Mean $\pm \mathrm{SEM} ; \mathrm{n}=5 ;{ }^{*} \mathrm{p}<0.05$ significant; ${ }^{a}$ as compared with the negative control; ${ }^{b}$ as compared with the positive control; NC, negative control; SD, positive control (standard drug) Effect of $\mathrm{J}$. tanjorensis aqueous leaf Extract on Packed Cell Volume (PCV)

The effect of aqueous leaf extract of $J$. tanjorensis on Packed Cell Volume was measured at pretreatment and post-treatment and presented in Table 4. The results showed that, PCV values of the groups treated with the extract increased in a dose dependent manner when compared with the negative control. Also the PCV values of groups treated with extract at 200 $\mathrm{mg} / \mathrm{kg}$ and $400 \mathrm{mg} / \mathrm{kg}$ showed significant increase than those administered with the standard drug.

Table 4: Effect of aqueous leaf extract of J. tanjorensis on Packed Cell Volume (PCV) in infected mice

\begin{tabular}{|lccc|}
\hline Test sample & Dose $(\mathrm{mg} / \mathrm{kg})$ & Pretreatment & Post treatment \\
NC & 10 & $25.01 \pm 1.31$ & $3.67 \pm 2.41$ \\
SD & 25 & $43.33 \pm 2.33$ & $36.01 \pm 1.22 * \mathrm{a}$ \\
Extract & 100 & $28.00 \pm 1.29$ & $29.67 \pm 1.30 * \mathrm{a}$ \\
Extract & 200 & $25.00 \pm 2.11$ & $44.25 \pm 1.20 * \mathrm{a}, \mathrm{b}$ \\
Extract & 400 & $26.75 \pm 2.21$ & $45.00 \pm 1.33 * \mathrm{a}, \mathrm{b}$
\end{tabular}

Notes: Values are presented as Mean $\pm \mathrm{SEM} ; \mathrm{n}=5 ;{ }^{*} \mathrm{p}<0.05$ significant; ${ }^{a}$ as compared with the negative control; ${ }^{b}$ as compared with the positive control; NC, negative control; SD, positive control (standard drug) Percentage parasitaemia count of mice before and after the treatment which did not clear the parasite on day four (Table 5). For survival time, only the mice in the positive control group survived till the end. All the The leaf extract of $J$. tanjorensis revealed a significant suppression activity of the parasites at the doses of $200 \mathrm{mg} / \mathrm{kg}$ and $400 \mathrm{mg} / \mathrm{kg}(\mathrm{p}<0.05)$ when compared with the negative control group mice in the negative control died off on the $4^{\text {th }}$ day while those administered with extracts died 10 - 15 days after.

Table 5: Effect of Aqueous leaf extract of J. tanjorensis on percentage parasitaemia, percentage suppression and mean survival time (MST)

\begin{tabular}{|llccc|}
\hline Test sample & Dose $(\mathrm{mg} / \mathrm{kg})$ & \% of parasitemia & \% of suppression & MST (days) \\
NC & 10 & $66.27 \pm 2.11$ & 0.00 & $1.32 \pm 00$ \\
SD & 25 & 0.00 & 100 & ND \\
Extract & 100 & $47.51 \pm 0.88$ & 45.00 & $7.00 \pm 0.31$ \\
Extract & 200 & $45.11 \pm 2.11$ & 25.50 & $7.53 \pm 0.33$ \\
Extract & 400 & $35.05 \pm 1.40$ & 60.72 & $9.67 \pm 1.30$
\end{tabular}

Notes: Values are presented as Mean $\pm \mathrm{SEM} ; \mathrm{n}=5 ; * \mathrm{p}<0.05$ significant; a as compared with the negative control; b as compared with the positive control; NC, negative control; SD, positive control (artemether/lumefantrine combined therapy); ND = no death within follow ups.

Discussion

One of the most devastating parasitic ailments arguably affecting most developing countries is malaria, impeding the progress of these countries and producing serious financial havoc (Radwick,
2016). Since there is no consistent drug against malaria that is not yet restrained due to resistance by the malaria parasite, it makes the situation dreadful (Gantz et. al., 2015). Discovering the active antiplasmodial components in medicinal plants can be a key to 
successfully control resistance of malaria parasites to anti malarial drugs (Franke-fayard, 2010). In this context, this research work assessed the antiplasmodial and antianaemic effect of Jatropha tanjorensis extracts on Plasmodium berghei infected mice in a bid to justify its name 'hospital too far'.

Plants are known to be rich sources of phytochemicals of medicinal importance. The phytochemical analysis of aqueous leaf extract of J. tanjorensis revealed the presence of alkaloids, tannins, saponins, flavonoids, terpe noids, cardiac glycosides and anthra quinones. These classes of secondary metabolites have been implicated for antimalarial and anti-anaemic activities in other plants (Okwu and Okwu, 2004). The antiplasmodial activity observed in this plant and other plants might be due to a single compound or synergistic action of several compounds. Plants which possess antiplasmodial properties are known to contain alkaloids like quinine. The presence of compounds like terpenoids, alkaloids and phenolic compounds present in the plant could be responsible for its antimalarial properties. The anti malarial efficacy of the extract might be attributed to another possible mechanism, that is, the immune strengthening property of the phytochemicals present. For example, Deressa et. al., 2010 reported the potential immune-modulatory effects of flavonoids. Hagazy et al., 2020 reported that alkaloids are known to intercalate with the parasite DNA while phenolics act by inhibiting protein and fatty acid (FAS II) biosynthesis in the parasite and counteracting the oxidative stress induced by the malaria parasite.

There is always fear that herbal drugs might contain some harmful metabolites thus, acute toxicity was addressed in this study. The oral acute toxicity of aqueous leaf extract of $\mathrm{J}$. tanjorensis at 2,000 and $5,000 \mathrm{mg} / \mathrm{kg}$ did not cause any morbidity or mortality which are critical signs of adverse effects of a drug on test animals. This shows that the LD50 is greater than 5,000 $\mathrm{mg} / \mathrm{kg}$ which attest to the safety of the plant (Falodun et al., 2013).

According to Carroll 2014, the clearance of uninfected RBC, the destruction of infected RBC and erythropoietic suppression have also been involved in mouse and human malaria associated anaemia. As a result, this study measured the total haemoglobin $(\mathrm{Hb})$ and packed cell volume (PCV) levels of the mice to check the efficacy of J. tanjorensis extract in preventing haemolysis and anaemia due to increased parasitemia.

According to Mengiste et al., 2012, an uncommon low haemoglobin level is indicative of anaemia. The result of this study showed that after treatment, the haemoglobin values of groups treated with the extract increased significantly when compared with negative control. Significantly, the decrease in PCV values of infected mice serves as a confirmatory symptom of anaemia in malaria infected mice. The administration of leaf extract of $J$. tanjorensis significantly increased $(p<0.05)$ the levels of packed cell volume (PCV) in a dose dependent manner. This suggests that the extract has potential anti-anaemic properties which supports its traditional use as a blood tonic.

The in vivo antiplasmodial activity of $J$. tanjorensis aqueous leaf extract was investigated to evaluate the curative activity of the extract during established infection. We found a dose dependent reduction in percentage suppression of parasitaemia and improved survival days. The standard drug exhibited the highest parasitaemia suppression of $0 \%$ while the negative control showed the lowest percentage suppression. This suggests that the extract had a suppressive effect on the erythrocyte infectivity and multiplication of the parasites in mice. These results accord closely with the work of Lusakabanzaa et al., (2010) which looked at in vitro and in vivo treatment of malaria using different medicinal plants used in Congolese traditional medicine. The mean survival time (MST) is a very important parameter to determine the antimalarial activity of any plant (Hagazy et al., 2020). The survival time of $P$. berghei infected mice were prolonged by the aqueous extract in a dose dependent manner. This might be attributed to the antioxidant effect of the secondary metabolites present in the plant extract which prevents the pathological effect of the parasite in the infected mice.

From the results of this investigation, the leaf extract had in vivo anti malarial and antianaemic properties which points to the fact that J. tanjorensis is a potential source for new drugs and useful dietary supplement as a nutraceutical. Jatropha tanjorensis represent a sustainable 
source of anti malaria agent which have unique modes of action and properties. Finally, bioactivity guided fractionation of the vegetable may reveal other pharmaceutical active constituents why it is called "hospital too far".

\section{References}

Carroll, J. (2014). New malaria drug unleashes an immune system assault on infected cells". fiercebiotechresearch.com.

Centers for Disease Control and Prevention (2015). Malaria Parasites - Biology. CDC: Malaria. U.S. Centers for Disease Control and Prevention. Collison, L. W. and Vignali, D. A. (2011). In vitro trey suppression assays method molecular biology. Clift. J. 707: 21-37.

Deressa, T., Mekonnen, Y. and Animut, A. (2010). In-vivo Antimalarial Activities of Clerodendrum myricoides, Dodonea angustifolia and Aloe debrana Against Plasmodium berghei. Ethio. J. Health Dev. 24:25-9.

Ehimwenma, S.O. and Osagie, A.U. (2007). Phytochemical screening and anti-anaemic effects of Jatropha tanjorensis leaf in protein malnourished rats. Plant Arch. 7: 509-516.

Falodun, A., Udu-cosi, A. A., Erharuyi, O., Imieje, V., Falodun, J. E., Agbonlahor, O. and Hamann, M. (2013). Jatropha tanjorensis. Review of Phytochemistry, Pharmacology and Pharmacotherapy. Journal of Pharmaceutical and Allied Sciences, 10 (3): 1955-1963.

Fenta, M. and Kahaliw, W. (2019). Evaluation of Antimalarial Activity of Hydromethanolic crude Extract and solvent fractions of leaves of Nuxia congesta R. Br. Ex. Fresen (Buddlejaceae) in Plasmodium berghei infected mice. Journal of Experimental Pharmacology. Vol 11: $121-134$.

Fentahun, S., Makonnen, E., Awas, T. and Giday, M. (2017). BMC Complementary and Alternative Medicine. Vol 17: 13.

Franke-Fayard, B. (2010). Sequestration and tissue accumulation of human malaria parasites: can we learn anything from rodent models of malaria? J. Pathog. 6 (9): 104-113.
Gantz, V.M., Jasinskiene, N., Tatarenkova, O., Fazekas, A., Macias, V.M., Bier, E. and James, A.A. (2015). Highly efficient Cas9-mediated gene drive for population modification of the malaria vector mosquito. Pro. Natl. Acad. Sci. 112: 20.

Hagazy, K., Sibhat, G. G., Karim, A., Tekulu, G. H., Periasamy, G. and Hiben, M. (2020). Antimalarial Activity of Meriandra dianthere leaf Extracts in Plasmodium berghei infected mice. Evidence-Based Complementary and Alternative Medicine. Vol 8:

Iwalewa, E.O., Adewunmi, C.O., Omisore, N.O., Adebanji, O.A. and Azike, C.K. (2005). ProAntioxidant effects and Cytoprotective potentials of nine edible vegetables in Southwest Nigeria. J. Med. Food. 8: 539-544.

Jigam, A.A., Abdulrazaq, U. and Egbuta, M.N. (2011). In-vivo antimalarial and toxicological evaluation of Chrozophora senegalensis A. Juss (Euphorbiaceae) extracts. J. Appl. Sci. 1: 90-4.

Lusakabanzaa, M., Mesiaa, G., Tonaa, G., Karemereb, S., Lukukab, A., Tits, M.L., Angenot, L. and Frederich, M. (2010). In vitro and in vivo antimalarial and cytotoxic activity of five plants used in Congolese traditional medicine. J. Ethnopharmacol. 129:398-402.

Mboowa, G. (2014). Genetics of Sub-Saharan African human population: implications for HIV/AIDS, tuberculosis and malaria. Int. J. Evol. Biol. 10: 82-91.

Mengiste, B., Makonnen, E. and Urga, K. (2012). In-vivo antimalarial activity of Dodonaea angustifolia seed extracts against Plasmodium Berghei in mice model. AJOL. 4:47-63.

Mojarrab, M., Shiravand, A., Delazar, A. and Afshar, H.F. (2014). Evaluation of in vitro antimalarial activity of different extracts of Artemisia aucheri Boiss. and A. armeniaca Lam. and fractions of the most potent extracts. J. World Sci. 82: 53-60.

Nayyar, G.M., Breman, J.G., Newton, P.N. and Herrington, J. (2012). Poor-quality antimalarial drugs in southeast Asia and sub-Saharan Africa. Lancet Infect. Dis. 12(6): 488-96. 
Oboh, F. O. J. and Masodje (2009). Nutritional and Antimicrobial properties of Jatropha tanjorensis leaves. American-Eurasian Journal of Scientific Research, 4(1): 7-10.

Okwu, D.E. and Okwu, M.E. (2004). Chemical composition of Spondias mombin Linn. Plant parts. J. Sust. Agric. Environ. 6 (2): 140-147.

Omobuwajo, O. R., Alade, G. O. Akanmu, M. A., Obutor, E. M. and Osasan, S. A. (2011). Microscopic and toxicity studies in the leaves of Jatropha tanjorensis. Afr. J. Pharm. Pharmacol. 5(1): 12-17.

Olayiwola, G., Iwalewa, E.O., Omobuwajo, O.R., Adeniyi, A.A. and Verspohi, E.J. (2004). The antidiabetic potential of jatropha tanjorensis leaves. Nig. J. Nat. Prod. Med., 8: 55-58.

Organization for Economic Co-operation and Development (OECD). Test No. 425: acute oral toxicity: up and down procedure. Paris: OECD Publishing; 2008.

Prabakaran, A. J. and Sujatha, M. (1999). Jatropha tanjorensis Ellis and saroja, a natural interspecific hybrid occurring in Tamil Nadu, India. Genetic Resources and Crop Evolution, 46:213-218.

Radwick, D. (2016). Can Malaria Be Eradicated? Council on Foreign Relations. Am. J. Public Health 53 (1): 17-21.

Von Scheuck, Falkensson, M. and Lundberg, B. (1986). Evaluation of hemocue, a new device for determining hemoglobin. Clin. Chem. 32: 526529.

World Health Organization (WHO) (2014). World Malaria Report. Geneva, Switzerland: World Health Organ. 4: 32-42. 